\title{
PERANAN GOOD CORPORATE GOVERNANCE DALAM MEMPREDIKSI FINANCIAL DISTRESS
}

\author{
Diah Mentari Cahyani ${ }^{(1)}$ \\ Ni Nyoman Ayu Diantini ${ }^{(2)}$ \\ (1), (2)Fakultas Ekonomi dan Bisnis Universitas Udayana (Unud), Bali, Indonesia \\ e-mail: diahmentari21@yahoo.com
}

\begin{abstract}
ABSTRAK
Penelitian ini bertujuan untuk mengetahui signifikansi pengaruh good corporate governance terhadap financial distress dengan variabel leverage, likuiditas, aktivitas, profitabilitas, dan penilaian/pasar sebagai variabel kontrol. Penelitian ini dilakukan pada perusahaan yang terdaftar di Bursa Efek Indonesia selama tahun 2012-2014. Teknik pengambilan sampel yang digunakan dalam penelitian ini adalah teknik purposive sampling. Sampel dari penelitian ini sebanyak 25 sampel perusahaandi Bursa Efek Indonesia periode 2012-2014. Teknik analisis data yang digunakan adalahuji analisis regresi logistik. Berdasarkan hasil dari analisis penelitian ditemukan good corporate governance berpengaruh negatif signifikan terhadap financial distress, likuiditas dan aktivitas berpengaruh negatif signifikan terhadap financial distress, leverage dan penilaian/pasar berpengaruh positif tidak signifikan terhadap financial distress, profitabilitas berpengaruh positif signifikan terhadap financial distress.

Kata Kunci : good corporate governance, leverage, likuiditas (CR), aktivitas (ITO), profitabilitas (ROA), penilaian/pasar (EPS), financial distress
\end{abstract}

\begin{abstract}
This study aims to determine the significance of the effect of good corporate governance to financial distress with leverage, activities, liquidity, profitability, and market valuation as control variables. This study was performed on companies listed in Indonesia Stock Exchange during 2012-2014. The sampling technique used in this research was purposive sampling technique. Samples from this study as many as 25 samples of companies in Indonesia Stock Exchange 2012-2014. The data analysis technique used logistic regression analysis. The resultfinds that good corporate governance influence negativelyon financial distress. Moreover liquidity and activitieshave negative effectson financial distress; leverage and market valuationhave not significant effectson the financial distress; and profitability has a positive effect on financial distres.

Keywords: good corporate governance, leverage, liquidity (CR), activities ( ITO), profitability (ROA), market valuation (EP), financial distress
\end{abstract}

\section{PENDAHULUAN}

Corporate financial distress merupakan bagian dari proses legal perusahaan dalam menuju kebangkrutan dan likuidasi (Altman dan Hotchkiss, 2006:3). Kondisi tersebut merupakan keadaan serius yang membawa perusahaan menuju kematian. Pada beberapa negara, kebangkrutan dan likuidasi bahkan didahului oleh keadaan financial distress perusahaan yang berkepanjangan dan akan membawa perusahaan pada kebangkrutan industri dan bahkan dapat menyebabkan bangkrutnya sebuah negara, oleh karenanya corporate financial distress menjadi perhatian banyak perusahaan dan negara dalam mencegah dan menanggulanginya.

Lin et al. (2008) mendefinisikan financial distress adalah kondisi dimana hutang perusahaan lebih besar dari ukuran perusahaan, profitabilitas, dan komposisi aset. Terjadinya penurunan pendapatan perusahaan dan arus kas yang tidak memadai dari operasi sehingga perusahaan mengalami penurunan likuiditas dan solvabilitas. Financial distress dimulai ketika perusahaan tidak dapat memenuhi jadwal pembayaran atau ketika proyeksi arus kas mengindikasikan bahwa perusahaan tersebut dengan segera tidak dapat memenuhi kewajibannya (Brigham dan Daves dalam Fachrudin, 2008).

Menurut Hanafi dkk dalam Rahayu, (2012) financial distress yang dihadapi perusahaan digambarkan diantara dua titik ekstrim, yaitu kesulitan keuangan jangka pendek (technical insolvency) sampai dengan tingkat yang insovabel (actual insolvency). Perusahaan yang mengalami technical insolvency akan segera mengalami kesulitan keuangan karena segera menghadapi tagihan para kreditnya. Perusahaan yang insovabel tapi tidak mengalami kesulitan jangka pendek masih dapat bekerja dengan baik, sehingga masih 
mempunyai kesempatan untuk memperbaiki solvabilitasnya, namun apabila tidak berhasil maka perusahaan tersebut akan mengalami kesulitan keuangan (financial distress).

Financial distress dapat terjadi karena adanya pengaruh dari dalam perusahaan sendiri (internal) maupun dari luar perusahaan (eksternal). Damodaran (2001) menyatakan, faktor penyebab financial distress dari dalam perusahan lebih bersifat mikro yaitu kesulitan arus kas, besarnya jumlah hutang, kerugian dalam kegiatan operasional perusahaan selama beberapa tahun.

Jika perusahaan mampu menutupi atau menanggulangi faktor internal tersebut, belum tentu perusahaan tersebut dapat terhindar dari financial distress. Karena masih terdapat faktor eksternal perusahaan yang menyebabkan financial distress. Menurut Damodaran menurut Radifan (2015) faktor eksternal perusahaan lebih bersifat makro,dan cakupannya lebih luas. Faktor eksternal dapat berupa kebijakan pemerintah yang dapat menambah beban usaha yang di tanggung perusahaan, misalnya tarif pajak yang meningkat yang dapat menambah beban perusahaan. Selain itu masih ada kebijakan suku bunga pinjaman yang meningkat, menyebabkan beban bunga yang ditanggung perusahaan meningkat.

Perusahaan yang sahamnya dihapus dari pencatatan atau delisting dan IPO oleh Bursa Efek Indonesia (BEI) pada periode 2009-2015. Pada tahun 2009 - 2015 di Indonesia setidaknya ada 28 perusahaan emiten yang telah dihapus pencatatan sahamnya (delisting) dari Bursa Efek Indonesia (BEI). Penghapusan pencatatan (Delisting) (Peraturan Bursa Nomor I-I tentang Penghapusan Pencatatan) adalah penghapusan efek dari daftar efek yang tercatat di bursa sehingga efek tersebut tidak dapat diperdagangkan di bursa. Terjadinya delisting beberapa perusahaan publik di Bursa Efek Indonesia (BEI) disebabkan karena kesulitan keuangan atau berada pada kondisi financial distress. Perusahaan yang delistingtersebut dikarenakan perusahaan tersebut tidak menunjukkan indikasi pemulihan yang memadai maka sesuai dengan peraturan bursa perusahaan tersebut mengalami involuntary delisting.

Terjadinya delisting beberapa perusahaan publik di Bursa Efek Indonesia (BEI) disebabkan karena kesulitan keuangan atau berada pada kondisi financial distress. Perusahaan yang delisting tersebut dikarenakan perusahaan tersebut tidak menunjukkan indikasi pemulihan yang memadai maka sesuai dengan peraturan bursa perusahaan tersebut mengalami involuntary delisting. Acuan yang dipakai oleh BEI dalam menghapus saham perusahaan tercatat adalah Peraturan Bursa Nomor I-I tentang Penghapusan Pencatatan (Delisting) dan Pencatatan Kembali (Relisting) Saham di Bursa Ketentuan III.3.I.I. Peraturan tersebut menyatakan bahwa BEI menghapus pencatatan saham perusahaan tercatat apabila perusahaan tercatat mengalami sekurang-kurangnya satu kondisi atau peristiwa, yang secara signifikan berpengaruh negatif terhadap kelangsungan usaha perusahaan tercatat sebagai perusahaan terbuka. Marosi dan Massoud (2007), menemukan bahwa perusahaan dengan tingkat pertumbuhan nilai yang rendah, tingkat leverageyang tinggi, dan momentum pasar yang rendah berpengaruh terhadap keputusan involuntary delisting. Ning et al., (2007), juga mengindentifikasi total aset, return onassets, dan total hutang terhadap aset sebagai variabel variabel yang berdampak signifikan terhadap delisting.

Altman dan Hotchkiss (2006:4) juga mengatakan bahwa kegagalan perusahaan bisnis dikaitkan dengan tahapan corporate financial distress yaitu failure, insolvency, defaults, dan bankruptcy. Failure berarti tingkat pengembalian dari investasi lebih rendah dibandingkan dengan investasi sejenis. Insolvency adalah ketidakmampuan purusahaan dalam memenuhi kewajiban jangka pendeknya yang akan segera jatuh tempo. Default adalah tahapan selanjutnya jika insolvency terjadi secara berkepanjangan. Defaults adalah ketidakmampuan perusahaan dalam memenuhi total kewajibannya, dan tahapan yang terakhir adalah Bankruptcy.

Good Corporate Governance (GCG) dalam upaya meningkatkan kinerja keuangan perusahaan, dibutuhkan tata kelola perusahaan yang efektif, efisien, dan ekonomis. Good Corporate Governance (GCG) merupakan bentuk pengelolaan perusahaan yang baik, dimana didalamnya tercakup suatu bentuk perlindungan terhadap kepentingan pemegang saham (publik) sebagai pemilik perusahaan dan kreditor sebagai penyandang dana ekstern. Sistem Corporate Governance (CG) yang baik akan memberikan perlindungan efektif kepada para pemegang saham dan kreditur untuk memperoleh kembali atas investasi dengan wajar, tepat dan seefisien mungkin, serta memastikan bahwa manajemen bertindak sebaik yang dapat dilakukannya untuk kepentingan perusahaan (The Indonesian Institute for Corporate Governance, 2006). 
Menurut Kaen dan Shaw dalam Kaihatu, (2006) ada empat komponen utama yang diperlukan dalam konsep Good Corporate Governance (GCG), yaitu fairness, transparency, accountability, dan responsibility. Keempat komponen tersebut penting karena penerapan prinsip Good Corporate Governance (GCG) secara konsisten terbukti dapat meningkatkan kualitas laporan keuangan dan juga dapat menjadi penghambat aktivitas rekayasa kinerja yang mengakibatkan laporan keuangan tidak menggambarkan nilai fundamental perusahaan.

Rasio likuiditas, yaitu mengukur kemampuan perusahaan untuk memenuhi kewajiban jangka pendeknya pada saat jatuh tempo (Wiagustini, 2014:87). Rasio likuiditas yang umum digunakan adalah current ratio, quick ratio, cash ratio, net working capital to sales, current assets to sales. Penelitian ini menggunakan current ratio. Menurut Sartono (2000:62) current ratio adalah rasio antara aktiva lancar dibagi dengan utang lancar. Current ratio untuk mengukur kemampuan perusahaan memenuhi kewajibannya yang segera jatuh tempo (Wiagustini, 2014:87). Rasio ini mengukur seberapa jauh aktiva lancar perusahaan bisa dipakai untuk memenuhi kewajiban lancarnya (Husnan, 2012:74).

Rasio aktivitas usaha, yaitu rasio untuk mengukur efektif tidaknya perusahaan dalam memanfaatkan sumber dananya (Wiagustini, 2014:87). Aktivitas diukur dengan menggunakan beberapa rasio yaitu inventory turnover, receivable turn over, fixed assets turnover, total assets turnover. Dalam penelitian ini menggunakan inventory turnover yangmengukur efektivitas penggunaan dana yang tertanam dalam persediaan (Wiagustini, 2014:89). Rasio perputaran persediaan (inventory turnover ratio), rasio ini dihitung dari membagi penjualan dengan persediaan (Brigham dan Houston, 2010:138). Inventory Turnover adalah rasio antara harga pokok penjualan atau penjualan dengan rata-rata persediaan yang mengukur efisiensi penggunaan persediaan (Sartono, 2000:63).

Kasmir (2012:197) menyatakan rasio profitabilitas adalah rasio yang memberikan ukuran tingkat efektivitas manajemen suatu perusahaan, karena menunjukkan laba yang dihasilkan dari penjualan dan pendapatan investasi. Rasio umum yang digunakan untuk mengukur profitabilitas adalah profit margin on sales, return on total assets, basic earning power, return on common equity. Dalam penelitian ini menggunakan Return on Total Assets, rasio ini adalah rasio antara laba setelah pajak (EAT) dengan total aktiva (Sartono, 2000:65).
Return on Total Assets mengukur kemampuan menghasilkan laba dari total aktiva yang digunakan (Wiagustini, 2014:90). Return on Investment (ROI) atau Return on Assets (ROA) menunjukkan berapa banyak laba bersih setelah pajak dapat dihasilkan dari (rata-rata) seluruh kekayaan yang dimiliki perusahaan (Husnan, 2012:76).

Brigham dan Joel (2006:110) menyatakan rasio nilai pasar (market value ratio), akan menghubungkan harga saham perusahaan pada laba, arus kas, dan nilai buku per sahamnya. Ada beberapa macam rasio yang digunakan untuk mengukur rasio nilai pasar yaitu earning per share, price earning ratio, market to book value, price to cash flow ratio, dividend payout ratio. Penelitian ini menggunakan Earning Per Share (EPS) yaitu untuk mengukur jumlah laba per lembar saham (Wiagustini, 2014:90).

Penelitian yang dilakukan oleh Kaihatu (2006) menyatakan bahwa empat komponen utama dalam konsep Good Corporate Governance (GCG), yaitu fairness, transparancy, accountability, dan responsibility secara konsisten terbukti dapat meningkatkan kualitas laporan keuangan perusahaan yang berarti pula dapat meningkatkan kinerja perusahaan dan menurunkan financial distress. Radifan (2015) menemukan bahwa penerapan GCG dapat menurunkan kemungkinan terjadinya financial distress.

Choirina (2015) menyatakan bahwa Good Corporate Governance (GCG) berpengaruh negatif terhadap probabilitas financial distress. Leal dan Silva (2005) di Brazil menyatakan bahwa dengan penerapan Good Corporate Governance (GCG) pada suatu perusahaan akan menurunkan cost of capital dan meningkatkan kinerja perusahaan yang berarti menurunkan kemungkinan financial distress. Sedangkan Ellen dan Juniarti (2013) menemukan bahwa penerapan GCG tidak berpengaruh signifikan dalam memprediksi financial distress perusahaan. Hasil serupa juga ditemukan oleh Juniarti dan Natalia (2012) menyatakan bahwa perusahaan yang memiliki GCG score yang tinggi dan memiliki predikat terpercaya memiliki default risk yang rendah. Hal ini juga didukung oleh fenomena di Indonesia yang dialami oleh perusahaan PT Garuda Indonesia (Persero) Tbk yang menerapkan GCG selama dua tahun berturut - turut dari tahun 2013 dan 2014 dan mendapatkan GCG score yang tinggi tetapi tetap mengalami kerugian di tahun 2013 dan 2014.

Fitdini (2009) meneliti hubungan mekanisme corporate governance, ukuran perusahaan, 
leverage, dan likuiditas terhadap financial distress. Penelitian tersebut menggunakan 28 perusahaan manufaktur yang terdaftar di BEI yang mengalami financial distress dan yang tidak mengalami financial distress untuk periode tahun 2004 - 2007. Dari beberapa variabel yang diteliti, variabel leverage, dan likuiditas perusahaan memiliki hubungan yang signifikan terhadap financial distress.

Berdasarkan research gap dan fenomena yang terjadi maka peran GCG masih menjadi pertanyaan dan perlu diteliti lebih lanjut dalam pengaruhnya terhadap financial distress dengan rasio kinerja keuangan sebagai variabel kontrol.

Berdasarkan pembahasan diatas, maka dapat dirumuskan pertanyaan penelitian yaitu apakah terdapat pengaruh signifikan Good Corporate Governance terhadap terjadinya Financial Distress? apakah terdapat pengaruh signifikan Leverage Ratio terhadap Financial Distress? apakah terdapat pengaruh signifikan Current Ratio terhadap Financial Distress? apakah terdapat pengaruh signifikan Inventory Turnover terhadap Financial Distress? apakah terdapat pengaruh signifikan Return on Assets terhadap Financial Distress? dan apakah terdapat pengaruh signifikan Earning Per Share terhadap Financial Distress?

Penelitian ini bertujuan untuk mengetahui pengaruh good corporate governance terhadap financial distress, untuk mengetahui signifikansi pengaruh leverage ratio terhadap financial distress, untuk mengetahui signifikasi pengaruh current ratio terhadap financial distress, untuk mengetahui signifikansi pengaruh inventory turnover terhadap financial distress, untuk mengetahui signifikansi pengaruh return on assets terhadap financial distress dan untuk mengetahui signifikansi pengaruh earning per share terhadap financial distress.

Penelitian yang dilakukan Triwahyuningtias (2012) menyatakan hasil bahwa GGG berpengaruh signifikan terhadap kemungkinan perusahaan mengalami financial distress. Hasil penelitian Dewi (2015) menyatakan bahwa GCG berpengaruh negatif dan signifikan terhadap financial distress. Hasil penelitian Nur (2007) juga menyatakan bahwa GCG berpengaruh signifikan dan negatif terhadap kondisi keuangan perusahaan. Berdasarkan temuantemuan tersebut, maka hipotesis penelitian ini adalah: $\mathbf{H}_{1}$ : Good Corporate Governance (GCG) Score berpengaruh negatif terhadap financial distress Penelitian yang dilakukan oleh Jiming dan Wei Wei (2011) menunjukkan bahwa leverage berpengaruh positif dan signifikan terhadap kondisi financial distress. Hasil penelitian ini juga sesuai dengan penelitian Andre (2009) yang menemukan bahwa leverage memiliki pengaruh yang signifikan dan positif dalam memprediksi financial distress. Utami (2009) menyatakan dalam penelitiannya juga menyatakan bahwa leverage mempunyai pengaruh positif dan signifikan dalam memprediksi financial distress pada perusahaan manufaktur yang terdaftar di Bursa Efek Indonesia periode 2009-2012. Berarti semakin tinggi leverage, maka probabilitas perusahaan mengalami financial distress semakin besar. Berdasarkan temuan-temuan tersebut, maka hipotesis penelitian ini adalah:

$\mathbf{H}_{2}$ : Leverage Ratio berpengaruh positif terhadap financial distress

Penelitian yang dilakukan oleh Almilia (2003) menunjukkan hasil bahwa current ratio memiliki pengaruh negatif dan signifikan untuk memprediksi financial distress pada perusahaan. Hal ini membuktikan bahwa semakin besar kemampuan perusahaan untuk memenuhi kewajiban jangka pendeknya maka semakin kecil kemungkinan terjadinya financial distress. Hal tersebut didukung oleh penelitian yang dilakukan oleh Atika dkk (2012) menunjukkan bahwa variabel current ratio berpengaruh signifikan dan negatif terhadap financial distress perusahaan. Penelitian ini diperkuat pula oleh penelitian Jiming dan Wei Wei (2011) serta Ellen dan Juniarti (2013) yang menunjukkan hasil yang sama. Berdasarkan temuan-temuan tersebut, maka hipotesis penelitian ini adalah:

$\mathbf{H}_{3}$ : Current ratio berpengaruh negatif terhadap Financial Distress

Penelitian Jiming dan Weiwei (2011) menyatakan bahwa rasio inventory turnover berpengaruh negatif dan signifikan terhadap terjadinya financial distress. Ardiyanto (2011) juga menyatakan bahwa inventory turnover berpengaruh negatif terhadap financial distress. Hal tersebut didukung oleh Ellen dan Juniarti (2013) menyatakan bahwa inventory turnover berpengaruh signifikan dan negatif terhadap financial distress. Berdasarkan temuan-temuan tersebut, maka hipotesis penelitian ini adalah :

$\mathbf{H}_{4}$ : Inventory Turnover berpengaruh negatif terhadap Financial Distress

Penelitian yang dilakukan oleh Andre (2009) melalui regresi logistik telah diketahui bahwa profitabilitas yang dihitung dengan Return on Assets (ROA) memiliki pengaruh yang signifikan dalam memprediksi financial distress. Hasil penelitian Hapsari (2012) menyatakan bahwa rasio profitabilitas (return on total assets) berpengaruh 
negatif dan signifikan terhadap kondisi financial distress perusahaan. Hal tersebut didukung oleh Widarjo dan Setiawan (2009) yang menyatakan profitabilitas yang diukur dengan menggunakan Return on Assets (ROA) berpengaruh negatif dan signifikan terhadap financial distress perusahaan. Berdasarkan temuan-temuan tersebut, maka hipotesis penelitian ini adalah :

$\mathbf{H}_{5}$ : Return on Assets (ROA) berpengaruh negatif terhadap financial distress

Penelitian yang dilakukan oleh Handajani (2013) menyatakan bahwa Earning Per Share (EPS) berpengaruh negatif dan signifikan terhadap financial distress. Ardiyanto (2011) menggunakan Earning Per Share (EPS) negatif selama beberapa tahun untuk penentuan kondisi distress perusahaan sesuai dengan penelitian Elloumi dan Gueyie (2001). Fitriyah dan Hariyati (2013) menyatakan bahwa perusahaan yang mengalami financial distress yaitu perusahaan yang memiliki Earning Per Share
(EPS) negatif dua tahun berturut-turut. Earning Per Share (EPS) banyak digunakan untuk mengevaluasi kinerja operasi dan profitabilitas perusahaan. Berdasarkan temuan-temuan tersebut, maka hipotesis penelitian ini adalah:

$\mathbf{H}_{6}$ : Earning Per Share berpengaruh negatif terhadap financial distress

\section{METODE}

Desain penelitian yang digunakan adalah asosiatif yaitu penelitian yang meneliti suatu hubungan antar variabel atau pengaruh variabel terhadap variabel lainnya (Sugiyono, 2012:55). Penelitian ini dilakukan untuk mengetahui pengaruh Good Corporate Governance (GCG), Leverage Ratio, Current Ratio, Inventory Turnover, Return on Assets (ROA), Earning Per Share terhadap Financial Distress. Berdasarkan teori dan hasil penelitian sebelumnya dapat disajikan kerangka konseptual seperti berikut.

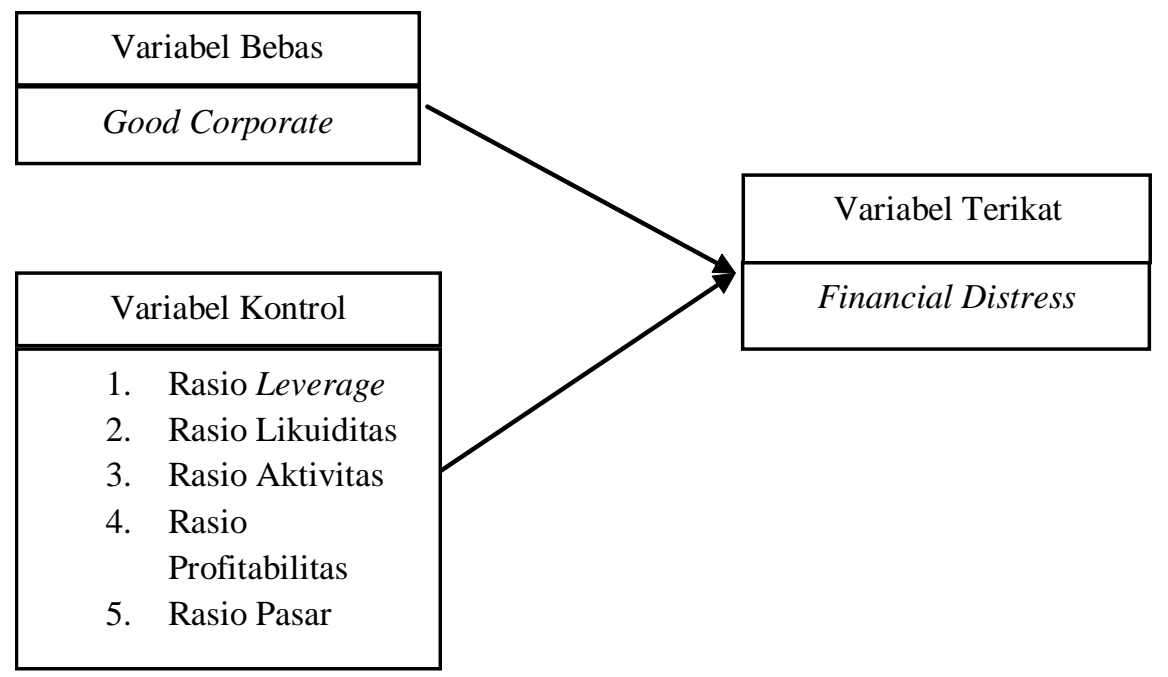

Gambar 1. Kerangka Konseptual

Sumber : Hasil Penelitian dan Publikasi Ilmiah

Penelitian ini dilakukan pada perusahaanperusahaan yang terdaftar di Bursa Efek Indonesia (BEI) yang menerapkan Good Corporate Governance (GCG) pada tahun 2012 - 2014. Objek penelitian ini adalah kondisi financial distress. Penelitian ini menggunakan tiga jenis variabel. Variabel terikat yang digunakan dalam penelitian ini adalah financial distress. Variabel bebas dalam penelitian ini adalah Good Corporate Governance (GCG). Variabel kontrol dalam penelitian ini adalah Rasio Leverage, Rasio Likuiditas, Rasio Aktivitas, Rasio Profitabilitas, Rasio Pasar.

Populasi yang digunakan dalam penelitian ini adalah perusahaan yang menerapkan Good
Corporate Governance dan perusahaan yang laporan keuangannya terdapat pada Bursa Efek Indonesia (BEI) pada periode 2012-2014.Sampel yang digunakan dalam penelitian ini menggunakan metode purposive sampling. Metode pengumpulan data dalam penelitian ini adalah metode observasi non partisipan yaitu metode pengumpulan data dengan pengamatan yang diperoleh dari www.idx.co.id. Periode pengamatan penelitian ini meliputi periode tahun 2012 - 2014 .

Teknik analisis data yang digunakan dalam penilitian ini adalah analisis regresi logistik. Regresi logistik (Logistic Regression) merupakan teknik analisis yang digunakan jika variabel terikatnya 
merupakan data kuantitatif (Variabel Dummy). Serta keunggulan dari regresi logistik dapat mengestimasi koefisien dan menguji signifikansi (Hosmer et al., 2013, 35). Analisis dalam penelitian ini menggunakan program software SPSS versi 13.0. Model regresi logistik yang digunakan adalah sebagai berikut.

$$
\begin{aligned}
\operatorname{Ln} \frac{p}{1-p}= & \alpha+\beta_{1} X_{1}+\beta_{2} X_{2}+\beta_{3} X_{3}+\beta_{4} X_{4}+\beta_{5} X_{5}+ \\
& \beta_{6} X_{6}+\varepsilon
\end{aligned}
$$

Dimana :

Ln $\frac{p}{1-p}$ : Financial Distress

$\operatorname{Ln} \frac{p}{1-p}=1$, jika tidak mengalami financial distress $\operatorname{Ln} \frac{p}{1-p}=0$, jika mengalami financial distress
$\alpha \quad:$ Konstanta
$\beta_{1-\mathrm{n}} \quad$ : Koefisien regresi
$\mathrm{X}_{1} \quad$ : Good Corporate Governance Score
$\mathrm{X}_{2} \quad$ : Leverage Ratio
$\mathrm{X}_{3} \quad$ : Current Ratio
$\mathrm{X}_{4} \quad$ : Inventory Turnover
$\mathrm{X}_{5} \quad$ : Return on Assets
$\mathrm{X}_{6} \quad$ : Earning Per Share
$\varepsilon \quad:$ Standard Error

\section{HASIL DAN PEMBAHASAN}

Statistik deskriptif dalam penelitian ini disajikan untuk memberikan informasi mengenai karakteristik variabel-variabel penelitian, antara lain minimum, maksimum, mean, dan deviasi standar.

Tabel 1. Hasil Uji Statistik Deskriptif Variabel Bebas dan Variabel Kontrol

\begin{tabular}{|c|c|c|c|c|c|c|c|}
\hline & & GCG & Leverage & $\mathrm{CR}$ & ITO & ROA & EPS \\
\hline \multirow[t]{2}{*}{$\mathrm{N}$} & Valid & 25 & 25 & 25 & 25 & 25 & 25 \\
\hline & Missing & 0 & 0 & 0 & 0 & 0 & 0 \\
\hline Mean & & 48,6023 & 189,7862 & 162,3917 & 34,0645 & 15,2683 & 140,8555 \\
\hline Median & & 47,3700 & 84,3800 & 168,5300 & 6,5000 & 10,5300 & 82,3300 \\
\hline $\begin{array}{l}\text { Std. } \\
\text { Deviation }\end{array}$ & & 22,32384 & 890,76556 & 124,54366 & 102,95335 & 13,60977 & 417,88036 \\
\hline Minimum & & 22,14 & 16,50 & 1,30 & 1,00 & 1,41 & $-0,01$ \\
\hline Maximum & & 76,75 & 1724,66 & 570,31 & 218,89 & 53,78 & 886,67 \\
\hline
\end{tabular}
$\left(\mathbf{X}_{1}, \mathbf{X}_{2}, \mathbf{X}_{3}, \mathbf{X}_{4}, \mathbf{X}_{5}, \mathbf{X}_{6}\right)$

Sumber: Data primer diolah, 2016

Berdasarkan Tabel 1, nilai minimum variabel GCG adalah 22,14. Nilai maksimum adalah 76,75. Nilai rata-rata variabel GCG adalah 47,3884 dengan standar deviasi 22,32384.

Berdasarkan Tabel 1, nilai minimum variabel Leverage adalah 16,50 . Nilai maksimum adalah 1724,66, artinya setiap Rp 100,00 ekuitas dijamin oleh hutang sebesar Rp 1724,66. Nilai rata-rata variabel Leverage adalah 189,7862 dengan standar deviasi 890,76556.

Berdasarkan Tabel 1, nilai minimum variabel Current Ratio adalah 1,30. Nilai maksimum adalah 570,31, artinya setiap Rp 100,00 kewajiban yang harus dibayar dijamin dengan dana lancar sebesar Rp 570,31. Nilai rata-rata variabel Current Ratio adalah 162,3917 dengan standar deviasi 124,54366.

Berdasarkan Tabel 1, nilai minimum variabel Inventory Turnover adalah 1,00 kali. Nilai maksimum adalah 218,89 , asumsi perhitungan hari dalam 1 tahun $=360$ hari, maka lamanya dana tertanam dalam persediaan adalah 1,64 hari. Nilai rata-rata variabel Inventory Turnover adalah 47,5952 dengan standar deviasi 102,95335.

Berdasarkan Tabel 1, nilai minimum variabel Return On Assets adalah 1,41. Nilai maksimum adalah 53,78, artinya bahwa setiap investasi sebesar Rp 100,00 menghasilkan laba bersih sebesar Rp 53,78. Nilai rata-rata variabel Return On Assets adalah 15,2683 dengan standar deviasi 13,60977.

Berdasarkan Tabel 1, nilai minimum variabel Earning Per Share adalah Rp -0,01 dan nilai maksimum adalah Rp 866,67, artinya setiap harga pasar saham sebesar Rp 100,00 akan menghasilkan laba per lembar saham sebesar $\mathrm{Rp} 866,67$. Nilai ratarata variabel Earning Per Share adalah Rp 140,8555 dengan standar deviasi Rp 417,88036.

Berdasarkan Tabel 2, yang dihasilkan, terdapat 11 observasi $(44,0 \%)$ perusahaan yang mendapat kategori non-distress sedangkan jumlah observasi perusahan yang mendapat kategori distress sebanyak 14 perusahaan $(56,0 \%)$. 
Tabel 2. Hasil Uji Statistik Deskriptif Variabel Dependen (Y)

\begin{tabular}{llrrrr}
\hline & & Frequency & Percent & Valid Percent & \multicolumn{2}{c}{$\begin{array}{c}\text { Cumulative } \\
\text { Percent }\end{array}$} \\
\hline Valid & Distress & 14 & 56,0 & 56,0 & 56,0 \\
& Non Distress & 11 & 44,0 & 44,0 & 100,0 \\
& Total & 25 & 100,0 & 100,0 & \\
\hline
\end{tabular}

Sumber: Data primer diolah, 2016

Tabel 3. Hasil Uji Hosmer and Lemeshow Test

\begin{tabular}{lllllr}
\hline \multicolumn{1}{c}{ Step } & Chi-square & Df & \multicolumn{2}{c}{ Sig. } \\
\hline 1 & & 4,714 & & 6 & 0,581 \\
\hline
\end{tabular}

Sumber: Data primer diolah, 2016

Berdasarkan Tabel 3, model regresi logistik pada penelitian ini menunjukkan nilai statistik Hosmer and Lemeshow Test sebesar 4,714 dengan probabilitas signifikansi 0,581 . Nilai signifikansi yang lebih besar dari $5 \%(0,581>0,05)$ ini menunjukkan bahwa model dalam penelitian ini dapat diterima karena cocok dengan data observasinya.

Tabel 4. Menilai Keseluruhan Model (Iteration History ${ }^{a, b, c}$ )

\begin{tabular}{lccc}
\hline & Iteration & -2 Log likelihood & Coefficients \\
& 1 & 34,296 & Constant \\
\hline Step & 2 & 34,296 & $-0,240$ \\
0 & 3 & 34,296 & $-0,241$ \\
& 3 & & $-0,241$ \\
\hline
\end{tabular}

Sumber: Data primer diolah, 2016

Tabel 5. Menilai Keseluruhan Model (Iteration History ${ }^{a, b, c, d}$ )

\begin{tabular}{|c|c|c|c|c|c|c|c|c|}
\hline \multirow[t]{2}{*}{ teration } & \multirow[b]{2}{*}{$\begin{array}{c}-2 \log \\
\text { likelihoo } \\
\text { d } \\
\end{array}$} & \multicolumn{7}{|c|}{ Coefficients } \\
\hline & & $\begin{array}{c}\text { Const } \\
\text { anta }\end{array}$ & GCG & $\begin{array}{l}\text { Levera } \\
\text { ge }\end{array}$ & $\mathrm{CR}$ & ITO & ROA & EPS \\
\hline 1 & 25,580 & 0,807 & $-0,013$ & 0,017 & $-0,077$ & $-0,014$ & 0,436 & 0,001 \\
\hline 2 & 23,514 & 1,315 & $-0,019$ & 0,021 & $-0,159$ & $-0,022$ & 0,777 & 0,001 \\
\hline 3 & 22,294 & 1,771 & $-0,025$ & 0,022 & $-0,270$ & $-0,028$ & 1,457 & 0,001 \\
\hline 4 & 19,945 & 2,877 & $-0,040$ & 0,023 & $-0,608$ & $-0,040$ & 3,946 & 0,002 \\
\hline 5 & 17,556 & 5,704 & $-0,074$ & 0,019 & $-1,428$ & $-0,071$ & 8,968 & 0,003 \\
\hline 6 & 17,250 & 7,111 & $-0,090$ & 0,016 & $-1,807$ & $-0,090$ & 11,347 & 0,004 \\
\hline 7 & 17,239 & 7,426 & $-0,093$ & 0,015 & $-1,895$ & $-0,094$ & 11,890 & 0,004 \\
\hline 8 & 17,239 & 7,441 & $-0,094$ & 0,015 & $-1,899$ & $-0,094$ & 11,917 & 0,004 \\
\hline 9 & 17,239 & 7,441 & $-0,094$ & 0,015 & $-1,899$ & $-0,094$ & 11,917 & 0,004 \\
\hline
\end{tabular}

Sumber: Data primer diolah, 2016

Berdasarkan Tabel 4 dan 5 didapat hasil penilaian keseluruhan model dimana nilai -2 Log likelihood pada awal adalah sebesar 34,296 dimana hanya menggunakan konstanta saja tanpa menggunakan variabel bebas dan variabel kontrol, sedangkan jika variabel Good Corporate Governance, Leverage Ratio, Current Ratio, Inventory Turnover, Return on Assets (ROA), Earning Per
Share dimasukkan kedalam model, maka nilai -2 log likelihood 17,239 yang berarti model dengan variabel Good Corporate Governance, Leverage Ratio, Current Ratio, Inventory Turnover, Return on Assets (ROA), Earning Per Share menunjukkan model regresi yang dibandingkan hanya dengan model konstanta saja atau dengan kata lain model yang dihipotesiskan cocok dengan data. 
Tabel 6. Koefisien Determinasi

\begin{tabular}{cccc}
\hline \multicolumn{4}{c}{ Model Summary } \\
\hline Step & -2 Log Likelihood & Cox \& Snell R & Nagelkerke R Square \\
& & Square & 0,663 \\
\hline
\end{tabular}

Sumber: Data primer diolah, 2016

Berdasarkan Tabel 6, menunjukkan nilai Nagelkerke R Square sebesar 0,663. Nilai tersebut berarti bahwa variasi GCG (variabel independen) dan leverage, CR, ITO, ROA, EPS (variabel kontrol) mampu menjelaskan variasi dari financial distress (variabel dependen) sebesar $66,3 \%$ sedangkan sisanya $33,7 \%$ dijelaskan oleh variasi variabel lain yang tidak dimasukkan dalam model persamaan regresi.

Tabel 7. Analisis Regresi Logistik

\begin{tabular}{|c|c|c|c|c|c|c|c|}
\hline \multicolumn{8}{|c|}{ Variables in the Equation } \\
\hline & & $\mathrm{B}$ & S.E. & Wald & Df & Sig. & $\operatorname{Exp}(B)$ \\
\hline \multirow[t]{7}{*}{ Step $1^{\mathrm{a}}$} & GCG & $-0,094$ & 0,047 & 3,895 & 1 & 0,048 & 0,911 \\
\hline & Leverage & 0,015 & 0,069 & 0,046 & 1 & 0,830 & 1,015 \\
\hline & CR & $-1,899$ & 0,963 & 3,888 & 1 & 0,049 & 0,150 \\
\hline & ITO & $-0,094$ & 0,045 & 4,412 & 1 & 0,036 & 0,910 \\
\hline & ROA & 11,917 & 5,918 & 4,055 & 1 & 0,044 & 149756,4 \\
\hline & EPS & 0,004 & 0,002 & 2,883 & 1 & 0,090 & 1,004 \\
\hline & Constant & 7,441 & 3,768 & 3,899 & 1 & 0,048 & 1704,855 \\
\hline
\end{tabular}

Sumber: Data primer diolah, 2016

Berdasarkan Tabel 7didapat model regresi yang terbentuk berdasarkan nilai estimasi parameter dalam Variables in The Equation sebagai berikut. $\operatorname{Ln} \frac{p}{1-p}=7,441-0,094 \mathrm{GCG}+0,015$ Leverage $1,899 \mathrm{CR}-0,094 \mathrm{ITO}+11,917 \mathrm{ROA}+$ $0,004 \mathrm{EPS}$

Berdasarkan Tabel 7 nilai konstanta yang diperoleh sebesar 7,441 menyatakan bahwa jika tidak ada variabel GCG, leverage, current ratio, inventory turnover, return on asset dan earning per share terjadi financial distress dari perusahaan. Nilai koefisien regresi variabel GCG perusahaan sebesar -0,094 menyatakan bahwa jika variabel leverage, current ratio, inventory turnover, return on asset, earning per share konstan, maka setiap peningkatan sebesar satu satuan GCG akan menurunkan resiko perusahaan mengalami kondisi financial distress sebesar 0,094.

Nilai koefisien regresi variabel leverage perusahaan yang diukur dengan rasio Debt to Equity Ratio (DER) adalah sebesar 0,015 menyatakan bahwa jika variabel GCG, current ratio, inventory turnover, return on asset, earning per share konstan, maka setiap peningkatan sebesar satu satuan leverage akan menurunkan resiko perusahaan mengalami kondisi financial distress sebesar 0,015 .

Nilai koefisien regresi variabel likuiditas perusahaan yang diukur dengan rasio Current Ratio
(CR) adalah sebesar -1,899 menyatakan bahwa jika variabel GCG, leverage, inventory turnover, return on asset, earning per share konstan, maka setiap peningkatan sebesar satu satuan current ratio akan menurunkan resiko perusahaan mengalami kondisi financial distress sebesar 1,899.

Nilai koefisien regresi variabel aktivitas perusahaan yang diukur dengan rasio Inventory Turnover (ITO) adalah sebesar -0,094 menyatakan bahwa jika variabel GCG, leverage, current ratio, return on asset, earning per share konstan, maka setiap peningkatan sebesar satu satuan inventory turnover akan menurunkan resiko perusahaan mengalami kondisi financial distress sebesar 0,094.

Nilai koefisien regresi variabel profitabilitas perusahaan yang diukur dengan rasio Return On Asset Ratio (ROA) adalah sebesar 11,917 menyatakan bahwa jika variabel GCG, leverage, current ratio, inventory turnover, earning per share konstan, maka setiap peningkatan sebesar satu satuan return on assets akan menurunkan resiko perusahaan mengalami kondisi financial distress sebesar 11,917 .

Nilai koefisien regresi variabel penilaian/pasar yang diukur dengan rasio Earning Per Share (EPS) adalah sebesar 0,004 menyatakan bahwa jika variabel GCG, leverage, current ratio, inventory turnover, return on asset konstan, maka setiap peningkatan sebesar satu satuan earning per share 
akan menurunkan resiko perusahaan mengalami kondisi financial distress sebesar 0,004.

Berdasarkan Tabel 7 Hipotesis pertama dalam penelitian ini diterima yaitu good corporate governance berpengaruh negatif signifikan terhadap financial distress diketahui bahwa koefisien good corporate governance bernilai 0,094 dengan nilai signifikansi $0,048<0,05$. Hipotesis kedua dalam penelitian ini ditolak yaitu leverage perusahaan berpengaruh positif signifikan terhadap financial distress diketahui bahwa koefisien leverage perusahaan bernilai positif sebesar 0,015 dengan nilai signifikansi $0,830>0,05$. Hipotesis ketiga dalam penelitian ini diterima yaitu current ratio perusahaan berpengaruh negatif signifikan terhadap financial distress diketahui bahwa koefisien current ratio perusahaan bernilai negatif sebesar -1,899 dengan nilai signifikansi 0,049 < 0,05.

Berdasarkan Tabel 7 Hipotesis keempat dalam penelitian ini diterima yaitu inventory turnover berpengaruh negatif signifikan terhadap financial distress diketahui bahwa koefisien inventory turnover bernilai negatif sebesar -0,094 dengan nilai signifikansi $0,036<0,05$. Hipotesis kelima dalam penelitian ini ditolak yaitu return on assets berpengaruh negatif signifikan terhadap financial distress diketahui bahwa koefisien return on assets bernilai positif sebesar 11,917 dengan nilai signifikansi $0,044<0,05$.Hipotesis keenam dalam penelitian ini ditolak yaitu earning per share berpengaruh negatif signifikan terhadap financial distress diketahui bahwa koefisien earning per share bernilai positif sebesar 0,004 dengan nilai signifikansi 0,090 >0,05.

Berdasarkan hasil analisis pada Tabel 7 menunjukkan bahwa good corporate governance berpengaruh negatif signifikan terhadap financial distress. Maka hipotesis pertama yang telah dirumuskan sesuai dengan hasil penelitian, sehingga H1 diterima.Hasil penelitian ini sesuai dengan penelitian yang dilakukan oleh Wardhani (2006), Triwahyuningtias (2012), Dewi (2015), dan Nur (2007) dalam penelitiannya menemukan bahwa bahwa good corporate governance berpengaruh negatif dan signifikan terhadap financial distress.

Hasil ini memberikan gambaran bahwa semakin baik penerapan corporate governance berdasarkan indeks corporate governance maka tekanan kondisi keuangan dapat dikurangi sehingga dapat menurunkan kondisi financial distress. Sebaliknya apabila semakin buruk penerapan corporate governance berdasarkan indeks corporate governance yang rendah maka akan meningkatkan tekanan kondisi keuangan perusahaan sehingga ada kemungkinan perusahaan mengalami financial distress. Hal tersebut didukung pernyataan dari Lizal (2002) bahwa salah satu penyebab dari financial distress yaitu dilihat dari bentuk tata kelola perusahaan (corporate governance) yang tak terpecahkan.

Berdasarkan hasil analisis pada Tabel 7 menunjukkan bahwa leverage yang diukur dengan Debt to Equity Ratio (DER) berpengaruh positif tidak signifikan terhadap financial distress. Maka hipotesis kedua yang telah dirumuskan tidak sesuai dengan hasil penelitian, sehingga $\mathrm{H}_{2}$ ditolak. Hasil penelitian ini tidak mendukung penelitian yang dilakukan Jiming dan Weiwei (2011), Andre (2009), dan Utami (2015) yang menyatakan bahwa leverage mampu mempengaruhi kemungkinan financial distress. Namun hasil penelitian ini memperkuat penelitian dari Ellen dan Juniarti (2013), Almilia dan Kristijadi (2003) serta Widarjo \& Setiawan (2009), Wongsosudono dan Chrissa (2013) yang menyatakan bahwa rasio leverage tidak berpengaruh signifikan terhadap financial distress.

Leverage menunjukkan proporsi penggunaan hutang untuk membiayai investasinya yang diproksikan dengan Debt to Equity Ratio (DER) (Sartono, 2010). Besarnya penggunaan hutang dibandingkan jumlah ekuitas dapat meningkatkan risiko perusahaan terkait dengan kesulitan keuangan. Namun hasil penelitian menunjukkan bahwa leverage tidak berpengaruh terhadap terhadap financial distress berarti tidak semua perusahaan yang tingkat leverage tinggi akanmengalami financial distress karena apabila perusahaan tersebut mampu mengelola dana yang di pinjamnya dengan baik maka akan mampu menghasilkan profit. Maka tidak semua perusahaan yang dibiayai oleh modal dari pihak eksternal akan mengalami financial distress.

Berdasarkan hasil analisis pada Tabel 7 menunjukkan bahwa current ratio berpengaruh negatif dan signifikan terhadap financial distress. Maka hipotesis ketiga yang telah dirumuskan sesuai dengan hasil penelitian, sehingga $\mathrm{H}_{3}$ diterima. Hasil ini mendukung penelitian dari Atika et al., (2012), Almilia dan Kristijadi (2003), Jiming dan Wei Wei (2011), Ellen dan Juniarti (2013) serta Pranowo et al. (2010) yang menyatakan bahwa current ratio berpengaruh negatif dan signifikan terhadap financial distress, dimana semakin tinggi rasio yang dihasilkan perusahaan akan semakin jauh dari kemungkinan terjadi financial distress.

Menurut Atika et al., (2012) menyebutkan bahwa rasio likuiditas yang menggunakan current 
ratio dalam pengukurannya signifikan berpengaruh negatif terhadap kemungkinan terjadinya financial distress di suatu perusahaan. Ini berarti bahwa semakin besar ketersediaan dana untuk melunasi kewajiban lancarnya, maka akan semakin kecil peluang perusahaan mengalami financial distress. Vitarianjani (2015) menyatakan likuiditas berpengaruh negatif terhadap kondisi financial distress karena likuiditas merupakan ukuran penilaian kinerja perusahaan yang dimaksudkan untuk mengukur kemampuan perusahaan membayar hutangnya (likuiditasnya).

Berdasarkan hasil analisis pada Tabel 7 menunjukkan bahwa inventory turnover berpengaruh negatif dan signifikan terhadap financial distress. Maka hipotesis keempat yang telah dirumuskan sesuai dengan hasil penelitian, sehingga $\mathrm{H}_{4}$ diterima. Hasil penelitian tersebut dapat diinterpretasikan bahwa inventory turnover berpengaruh negatif dan signifikan terhadap financial distress perusahaan yang terdaftar di BEI periode 2011- 2014. Hasil ini mendukung penelitian dari Ellen dan Juniarti (2013), Jiming dan Weiwei (2011), Ardiyanto (2011) yang menyatakan bahwa inventory turnover berpengaruh negatif dan signifikan terhadap financial distress, semakin tinggi inventory turnover semakin rendah kemungkinan perusahaan mengalami financial distress.

Hasil penelitian ini sesuai dengan teori yang dikemukakan oleh Kasmir (2012:180) inventory turnover yang tinggi menunjukkan perusahaan bekerja secara efisien, dan likuid persediaan semakin baik. Artinya, semakin tinggi inventory turnover maka persediaan akan cepat berubah menjadi uang kas dan perusahaan akan terhindar dari kondisi financial distress. Menurut Hendra (2009:204) menyatakan bahwa inventory turnover dalam perusahaan menunjukkan kinerja perusahaan dalam aktivitas operasionalnya. Semakin tinggi inventory turnover maka semakin besar kemungkinan perusahaan akan memperoleh keuntungan.

Berdasarkan hasil analisis pada Tabel 7, bahwa return on assets berpengaruh positif dan signifikan terhadap financial distress. Maka hipotesis kedua yang telah dirumuskan tidak sesuai dengan hasil penelitian, sehingga $\mathrm{H}_{5}$ ditolak. Hasil penelitian tersebut dapat diinterpretasikan bahwa inventory turnover berpengaruh positif dan signifikan terhadap financial distress perusahaan yang terdaftar di BEI periode 2011-2014.Hasil ini tidak mendukung penelitian dari Widarjo dan Setiawan (2009), Andre (2009), Altman (1968) yang menyatakan bahwa rasio profitabilitas yang diukur dengan return on assets berpengaruh negatif dan signifikan terhadap financial distress.

Rasio profitabilitas merupakan hasil akhir bersih dari berbagai keputusan, dimana rasio ini digunakan sebagai alat pengukur atas kemampuan perusahaan untuk memperoleh keuntungan dari setiap penjualan yang dihasilkan.Profitabilitas adalah tingkat keberhasilan atau kegagalan perusahaan selama jangka waktu tertentu (Atmini, 2005). Perusahaan yang menguntungkan cenderung untuk meningkatkan jumlah hutangnya sehingga rangking kreditnya juga meningkat sehingga kemungkinan financial distress juga semakin tinggi (Avramov et al., 2013).

Berdasarkan hasil analisis pada Tabel 7, menunjukkan bahwa earning per share berpengaruh positif dan tidak signifikan terhadap financial distress. Maka hipotesis keenam yang telah dirumuskan tidak sesuai dengan hasil penelitian, sehingga $\mathrm{H}_{6}$ ditolak. Earning Per Share (EPS) yang dapat digunakan untuk menunjukkan kemampuan perusahaan dalam memberikan laba bersih tahun berjalannya yang distribusikan kepada pemiliki entitas induk perusahaan dalam suatu periode. Perusahaan yang mengalami financial distress ditandai dengan perusahaan memiliki EPS negatif selama dua tahun atau lebih secara berturut-turut, dan perusahaan yang cenderung tidak mengalami financial distress ditandai dengan tidak memiliki EPS negatif selama dua tahun atau lebih secara berturut-turut.

Whitaker dalam Agusti (2013) menyatakan sebuah perusahaan memiliki pertumbuhan yang baik di masa yang akan datang apabila memiliki Earning Per Share (EPS) positif secara terus menerus pada setiap periodenya. Sebaliknya, EPS yang negatif dalam beberapa periode menggambarkan prospek earning dan pertumbuhan perusahaan yang tidak baik, sehingga hal tersebut kurang menarik bagi para investor. Saat kondisi seperti itu perusahaan akan sulit untuk mendapatkan dana dari luar perusahaan dikarenakan pendapatannya yang negatif, sehingga dapat meningkatkan perusahaan mengalami kondisi financial distress.

\section{SIMPULAN DAN SARAN}

Berdasarkan hasil analisis penelitian dan hasil pembahasan diatas maka, dapat ditarik beberapa kesimpulan yaitu Good Corporate Governance berpengaruh negatif signifikan terhadap financial distress pada perusahaan yang terdaftar di Bursa Efek Indonesia periode 2011 - 2014. Leverage berpengaruh positif tidak signifikan terhadap financial distress. Likuiditas berpengaruh negatif 
signifikan terhadap financial distress. Aktivitas berpengaruh negatif signifikan terhadap financial distress. Profitabilitas berpengaruh positif signifikan terhadap financial distress. Penilaian Pasar berpengaruh positif tidak signifikan terhadap financial distress.

Berdasarkan simpulan, maka saran yang dapat diberikan adalah Manajer perusahaan sebaiknya menerapkan good corporate governance dengan baik sehingga terhindar dari financial distress dan diharapkan terus memperhatikan faktor - faktor yang mempengaruhi financial distress seperti good corporate governance, likuiditas, aktivitas, profitabilitas dan mengelola leverage dengan baik agar perusahaan terhindar dari financial distress. Bagi peneliti selanjutnya, disarankan agar menggunakan variabel lainnya selain Good Corporate Governance seperti struktur kepemilikan dan variabel makro, dan menambah rentang waktu atau periode penelitian, sehingga hasil yang diperoleh akan lebih akurat.

\section{REFERENSI}

Agusti, C. P. 2013. Analisis Faktor yang Mempengaruhi Kemungkinan Terjadinya Financial Distress. Skripsi. Universitas Diponegoro, Semarang.

Almilia, L. S. dan E. Kristijadi. 2003. Analisis Rasio Keuangan untuk Memprediksi Kondisi Financial Distress Perusahaan Manufaktur yang terdaftar di Bursa Efek Jakarta. Jurnal Akuntansi dan Auditing Indonesia, 7 (2): 183-206.

Altman, E. I. 1968. Financial Ratios: Discriminan Analysis and The Prediction of Coprate Bankrupty. Journal of Finance. 123.

Altman, E. I, and Edith H. 2006. Corporate Financial Distress and Bankruptcy. Third Edition. Hoboken, New Jersey: John Wiley \& Sons, Inc.

Andre, O. 2009. Pengaruh Profitabilitas, Likuiditas dan Leverage Dalam Memprediksi Financial Distress (Studi Empiris Pada Perusahaan Aneka Industri yang Terdaftar di BEI). Skripsi. Fakultas Ekonomi, Universitas Negeri Padang. Ardiyanto, F. D. 2011. Prediksi Rasio Keuangan Terhadap Kondisi Financial Distress Perusahaan Manufaktur yang Terdaftar di BEI. Jurnal Dinamika Ekonomi dan Bisnis, 8 (1): 1-14.

Asquith P., R. Gertnen and D. Scharfstein. 1994. Anatomy of Financial Distress: An examination of Junk-Bond Issues. Quarterly Journal of Economics, 109: 1189-1222.

Atika, D, dan Siti R. H. 2012. Pengaruh Beberapa Rasio Keuangan Terhadap Prediksi Kondisi
Financial Distress (Studi Pada Perusahaan Tekstil dan Garmen yang Terdaftar di Bursa Efek Indonesia Periode 2008-2011). Jurnal Ekonomi Bisnis dan Akuntansi, 11 (2): 61-76.

Avramov, D, Tarun C, Gergana J, and Alexander P. 2013. Anomalies and Financial Distress. Journal of Financial Economics, 108: 139159.

Fachrudin, K.A. 2008. Faktor-faktor yang Meningkatkan Peluang Survive Perusahaan Kesulitan Keuangan. Jurnal Manajemen Bisnis, 1(1): 1-9.

Brigham, E. F dan Joel F. H 2010. Dasar-dasar Manajemen Keuangan. Edisi 11, Buku 1. Jakarta: Salemba Empat

Choirina, P. M. 2015. Analisis Faktor - Faktor yang Mempengaruhi Probabilitas Financial Distress Perbankan Indonesia. Skripsi. Fakultas Ekonomika dan Bisnis, Universitas Diponegoro.

Dewi, U. K. 2015. Pengaruh Corporate Governance Terhadap Financial Distress Pada Perusahaan Properti dan Real Estate di Indonesia. Skripsi. Fakultas Ekonomi, Universitas Syiah Kuala.

Ellen dan Juniarti. 2013. Penerapan Good Corporate Governance, Dampaknya Terhadap Prediksi Financial Distress Pada Sektor Aneka Industri dan Barang Konsumsi. Business Accounting Review, 1 (2): 1-13.

Elloumi, F. an d Gueyie, J. P. 2001. Financial Distress and Corporate Governance: An Empirical Analysis. Corporate Governance, 1 (1): 15-23.

Fitdini, J. E, 2009. Hubungan Struktur Kepemilikan, Ukuran Dewan, Dewan Komisaris Independen, Ukuran Perusahaan, Leverage, dan Likuiditas dengan Kondisi Financial Distress. Skripsi, Universitas Diponegoro.

Fitriyah, I, dan Hariyati. 2013. Pengaruh Rasio Keuangan Terhadap Financial Distress pada Perusahaan Properti dan Real Estate. Jurnal Ilmu Manajemen, 1 (3): 760 - 773.

Handajani, S. 2013. Pengaruh Kinerja Keuangan Terhadap Financial Distress pada Perusahaan Perbankan di BEI Pada Tahun 2008-1011. Jurnal Keuangan, 2 (3): 1-4.

Hendra S. R. P. 2009. Manajemen Keuangan dan Akuntansi Untuk Eksekutif Perusahaan. Jakarta: Salemba Empat.

Husnan, S. 2012. Dasar-dasar Manajemen Keuangan. Edisi Keenam. Yogyakarta: Unit Penerbit dan Percetakan (UPP STIM YKPN).

Hofer, C. W. 1980. Turnaround Strategies. Journal of Business Strategy, 1: 19-31. 
Hosmer, D. W., Lemeshow, Stanley and Sturdivant, Rodney X. 2013. Applied Logistic Regression, e-book, accessed 21 July 2016.

Jiming, L, and Weiwei, D. 2011. An Empirical Study on the Corporate Financial Distress Prediction Based on Logistic Model Evidence from China's Manufacturing Industry. International Journal of Digital Content Technology. 5 (6): 368-379.

Kaihatu, T. S. 2006. Good Corporate Governance dan Penerapannya di Indonesia. Jurnal Manajemen dan Kewirausahaan, 8 (1): 1-9.

Kasmir. 2010. Pengantar Manajemen Keuangan. Edisi Pertama. Jakarta: Kencana Prenada Media Group.

Kasmir. 2012. Analisis Laporan Keuangan. Cetakan ke-5. Jakarta: PT Raja Grafindo Persada.

Leal, R. P. C., Carvalhal and Silva. A. L. 2004. Corporate Governance and Value in Brazil (and in Chile). Unpublished Thesis, University of Rio de Janeiro. Brazil.

Lin, Beixin, Zu-Hsu L, Lance G. Gibbs. 2008. Operational restructuring: Reviving an ailing business. In: Management Decision, 46 (4): 539-552.

Lizal, L. 2002. Determinants of Financial Distress: What Drives Bankruptcy in a Transition Economy? The Czech Republic Case. William Davidson Working Paper. 451.

Marosi, A dan Nadia, M. 2007. Why Do Firms Go Dark?. Journal of Financial and Quantitative Analysis, 42 (2): 421.

Ning, Y., W. N. Davidson III, and K. Zhong. 2007. The Variability of Board Size Determinants: An empirical Analysis. Journal of Applied Finance, 17 (2): 48-61.

Nur, DP. E. 2007. Analisis Pengaruh Praktek Tata Kelola Perusahaan terhadap Kesulitan Keuangan. Jurnal Bisnis dan Akuntansi, 9 (1): 88-102.

Pranowo, K., Achsani. N. A., Manurung. A. H., and Nuryartono. N. 2010. Determinant of Corporate Financial Distress in an Emerging Market Economy: Empirical Evidence From Indonesian Stock Exchange 2004-2008. International Research Journal of Finance and Economics - Issue, 52.
Radifan, R. 2015. Analisis Pengaruh Mekanisme Good Corporate Governance Terhadap Kemungkinan Financial Distress. Skripsi. Fakultas Ekonomika dan Bisnis, Universitas Diponegoro.

Rahayu, S. 2012. Moderasi Reputasi Auditor Terhadap Faktor-Faktor yang Mempengaruhi Auditor Switching pada Perusahaan Industri Manufaktur yang Terdaftar di BEI pada Tahun 2006-2010. Tesis. Program Studi Magister Akuntansi, Universitas Esa Unggul.

Sartono, A. R. 2000. Ringkasan Teori Manajemen Keuangan. Edisi 3. Yogyakarta: BPFE.

Sugiyono. 2012. Metode Penelitian Bisnis (Pendekatan Kuantitatif, Kualitatif, dan $R \& D)$. Cetakan ke-16. Bandung: Alfabeta.

Triwahyuningtias, M. 2012. Analisa Pengaruh Struktur Kepemilikan, Ukuran Dewan, Komisaris Independen, Likuiditas dan Leverage Terhadap Terjadinya Kondisi Financial Distress. Unpublished Thesis, Universitas Diponegoro.

Utami, M. 2009. Pengaruh Aktivitas, Leverage, dan Pertumbuhan Peruahaan Dalam Memprediksi Financial Distress (Studi Empiris pada Perusahaan Manufaktur yang Terdaftar di BEI Periode 2009-2012). Skripsi. Fakultas Ekonomi Universitas, Negeri Padang.

Vitarianjani, N. 2015. Prediksi Kondisi Financial Distress dan Faktor yang Mempengaruhi Studi Empiris pada Perusahaan Batubara yang Terdaftar di Bursa Efek Indonesia Tahun 20112014. Artikel Ilmiah Mahasiswa. Fakultas Ekonomi, Universitas Jember.

Wardhani, R. 2006. Mekanisme Corporate Governance Dalam Perusahaan yang Mengalami Permasalahan Keuangan. Unpublished Thesis, Universitas Indonesia.

Whitaker, R. B. 1999. The Early Stages of Financial Distress. Journal of Economics and Finance, 23 (2): 123-132.

Wiagustini, N. L. P. 2014. Manajemen Keuangan. Cetakan Pertama. Udayana University Press.

Widarjo, W, dan Doddy, S. 2009. Pengaruh Rasio Keuangan Terhadap Kondisi Financial Distress Perusahaan Otomotif. Jurnal Bisnis dan Akuntansi, 11 (2): 107-119. 